\title{
Microzooplankton grazing before, during and after a cyanobacterial bloom in Vancouver Lake, Washington, USA
}

\author{
Jennifer Boyer, Gretchen Rollwagen-Bollens*, Stephen M. Bollens \\ School of Earth and Environmental Sciences, Washington State University Vancouver, \\ Vancouver, Washington 98686, USA
}

\begin{abstract}
We conducted 16 dilution experiments from April 2008 to January 2009 to estimate microzooplankton grazing and intrinsic phytoplankton growth rates before, during and after a bloom of filamentous cyanobacteria in Vancouver Lake, Washington, USA. Intrinsic phytoplankton growth rates were low in April $\left(\sim 0.4 \mathrm{~d}^{-1}\right)$, increased to a maximum $\left(1.2 \mathrm{~d}^{-1}\right)$ in May, and then declined to zero and became negative in June and early July, prior to a phytoplankton bloom dominated by cyanobacteria (Aphanizomenon flos-aquae). Phytoplankton growth rates rose as the bloom progressed, reaching rates $>1.0 \mathrm{~d}^{-1}$ in August and September, then declined through autumn. Spring microzooplankton grazing rates were low $\left(-0.3\right.$ to $\left.0.3 \mathrm{~d}^{-1}\right)$, then became substantially negative $(-1.1$ to $-1.5 \mathrm{~d}^{-1}$ ) preceding the chlorophyll a bloom. During the bloom, grazing rates quickly increased to a maximum of $0.8 \mathrm{~d}^{-1}$ and remained high as the bloom declined. Microzooplankton grazing specifically on cyanobacteria was high in spring $\left(1.0 \mathrm{~d}^{-1}\right)$, negative just before the bloom $\left(-0.7 \mathrm{~d}^{-1}\right.$ to $\left.-1.0 \mathrm{~d}^{-1}\right)$, and low in autumn $\left(0.3\right.$ to $\left.0.7 \mathrm{~d}^{-1}\right)$. Negative grazing on cyanobacteria immediately before the bloom may have been due to preferential grazing on other co-occurring prey, thus enabling the bloom to form, while higher grazing rates on cyanobacteria, especially on Aphanizomenon flos-aquae, in autumn is likely to have contributed to the bloom's decline. These findings show that microzooplankton can potentially influence cyanobacterial blooms directly and indirectly through grazing.
\end{abstract}

KEY WORDS: Microzooplankton · Grazing · Aphanizomenon flos-aquae · Harmful algal bloom • Eutrophication · Cyanobacteria

\section{INTRODUCTION}

Over the past several decades, aquatic systems have been increasingly impacted by excessive nutrient inputs from agriculture, livestock production, urbanization and industry, leading to dramatic increases in phytoplankton blooms globally (Allan 1995, Carpenter et al. 1999, Havens 2008). Moreover, in the past decade there have been more harmful algal blooms (HABs) of greater geographic extent, longer duration-and involving more toxic species - than in preceding decades (Smayda 1990, Hallegraeff 1993, Anderson et al. 2002, Glibert et al. 2005). A particular problem is the formation of harmful blooms of cyanobacteria, the most pervasive and problematic noxious freshwater algal taxa worldwide (Carmichael 1997, Codd 1998, Chorus \& Falconer 2000, Chorus 2001, Heisler et al. 2008).

Blooms of cyanobacteria lead to increased turbidity, decreased biodiversity, oxygen depletion, and, in many cases, toxin production, resulting in significant degradation of the quality of water for drinking, agriculture, and as wildlife habitat (Carpenter et al. 1999, Codd 2000). Cyanobacterial blooms can sometimes be fatal to wild and domestic animals (Beasley et al. 1989) and they pose serious health risks to humans, including increased incidences of liver cancer (Wu et al. 2006) and a 2-fold increase in respiratory problems 
after exposure to high levels of cyanobacterial toxins in recreational waters (Stewart et al. 2006).

Cyanobacterial blooms are typically associated with eutrophic, poorly flushed waters (Codd 2000, Anderson et al. 2002, Heisler et al. 2008). However, the precise chemical and physical factors required for cyanobacterial blooms are uncertain and vary from habitat to habitat. Typically, excessive nitrogen and phosphorus (e.g. Elser 1999), low nitrogen-to-phosphorus ratios (Smith 1983, Elser 1999, Oliver \& Ganf 2000), and temperatures around 20 to $25^{\circ} \mathrm{C}$ (Celik \& Ongun 2006, de Figueiredo et al. 2006, Yamamoto 2009) will favor cyanobacterial blooms.

However, in addition to physical and chemical environmental parameters, top-down factors such as zooplankton grazing on cyanobacteria can also influence bloom formation. Most research has focused on the role of mesozooplankton (typically crustaceans $>200 \mu \mathrm{m}$, e.g. copepods and cladocerans) grazers in controlling HABs (e.g. Epp 1996, Elser 1999, Panosso et al. 2003, Mitra \& Flynn 2006). Previous studies have found that the survival of mesozooplankton grazers is negatively affected by the presence of toxic cyanobacteria (namely, Microcystis spp.; Lürling 2003, Wilson et al. 2006) and that filamentous cyanobacteria with low levels of mucilage are grazed more than single-celled cyanobacteria with high levels of mucilage (Wilson et al. 2006). Despite findings that mesozooplankton such as Daphnia spp. can successfully graze on cyanobacteria and reduce their abundance (Epp 1996, Elser 1999, Paterson et al. 2002), cyanobacteria are generally considered a poor food source for mesozooplankton because they inhibit grazing and may produce cyanotoxins that have negative physiological effects on mesozooplankton (Hambright et al. 2001, Lürling 2003, Wilson et al. 2006).

In addition to crustacean grazers, microzooplankton (heterotrophic-mixotrophic protists $<200 \mu \mathrm{m}$ in size, e.g. dinoflagellates and ciliates) may also influence the dynamics of cyanobacterial blooms. In marine and estuarine systems, numerous studies have demonstrated the substantial grazing impact of microzooplankton on primary producers generally (Calbet \& Landry 2004, Leising et al. 2005, Calbet 2008), as well as on the timing, composition and potential magnitude of algal blooms, including blooms of harmful taxa (Henjes et al. 2007, Demir et al. 2008). Grazing of cyanobacteria by heterotrophic protists has been observed in the laboratory (reviewed in Dryden \& Wright 1987), and several experimental studies have documented micrograzers consuming small, solitary cyanobacterial cells - which stimulated cyanobacterial colony development, possibly as a refuge from grazing (Fialkowska \& Pajdak-Stos 2002, Jakobsen \& Tang 2002, Yang et al. 2006); this has suggested a possible role for freshwater microzooplankton in modulating the timing and rate of cyanobacterial colony formation.

However, the role of grazing by microzooplankton on the dynamics of freshwater cyanobacterial blooms has rarely been considered in the field, especially in lake systems. In one study of a subtropical riverine system, Leonard \& Paerl (2005) found that microzooplankton grazing rates were highest during a cyanobacterial bloom, demonstrating a greater microzooplankton grazing impact on phytoplankton when cyanobacteria were abundant. In addition, Gobler et al. (2007) found that grazing by microzooplankton on phytoplankton in a eutrophic temperate lake was consistent throughout a summer cyanobacterial bloom, and that microzooplankton did not appear to be affected by toxin levels. The results from these few studies, combined with the findings from laboratory experiments, suggest a high potential for micrograzers to both directly and indirectly influence colony formation by cyanobacteria, and bloom development, thus highlighting the need to better understand and quantify the impact of grazing by microzooplankton on the formation of cyanobacterial blooms in lakes.

Vancouver Lake, a large, shallow, turbid lake located in southwest Washington State, has experienced seasonal blooms of cyanobacteria for over $20 \mathrm{yr}$ (Wierenga 2005). As part of a larger investigation into the biological factors that may influence cyanobacterial blooms in Vancouver Lake, our objective in this study was to quantify microzooplankton grazing rates on algae and cyanobacteria over the course of a summer bloom cycle of cyanobacteria in order to assess the influence of microzooplankton grazing on bloom formation and decline.

\section{MATERIALS AND METHODS}

Study area. Vancouver Lake is located in the lower Columbia River floodplain in southwest Washington State $\left(45.68^{\circ} \mathrm{N}, 122.72^{\circ} \mathrm{W}\right.$, Fig. 1). The lake has an area of $\sim 5680$ ha, a mean depth of $0.6 \mathrm{~m}$, and it is highly turbid, with mostly unconsolidated sediments and no macrophytes (Caromile et al. 2000, G. RollwagenBollens unpubl. data). Vancouver Lake is connected hydrologically to the Columbia River by Lake River to the north and it receives additional input from Burnt Bridge Creek to the east. The lake also has a gated flushing channel on the southwest shoreline to allow inflow from the Columbia River. We collected all samples from the end of a dock at a private sailing club located on the eastern shore of the lake (Fig. 1). Previous sampling, conducted at 8 different locations throughout the lake in the year prior to our study, found the abundance and taxonomic composition of 


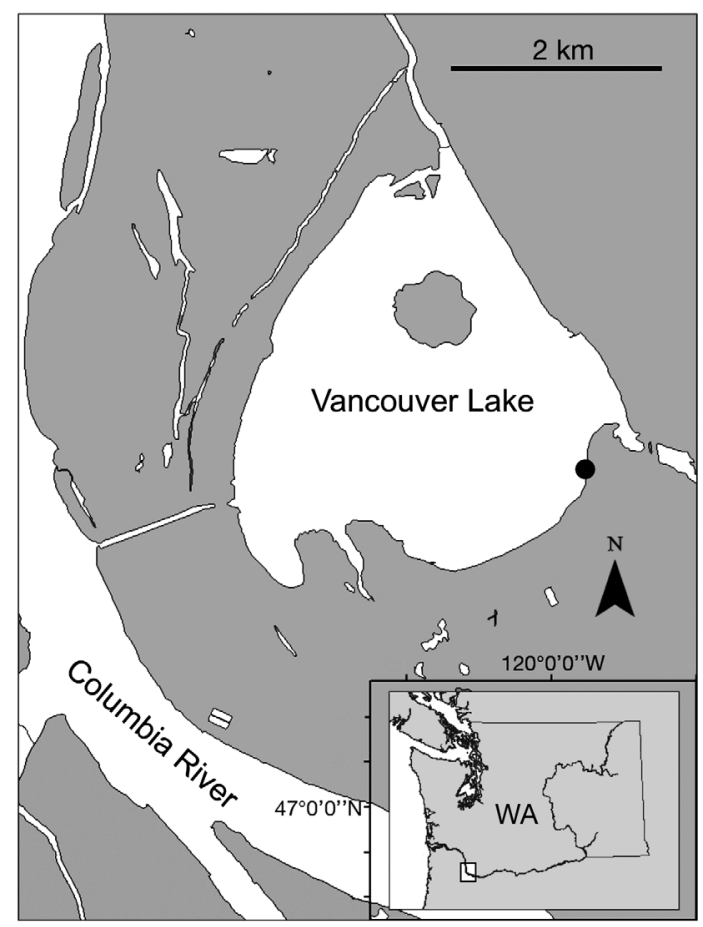

Fig. 1. Vancouver Lake, Washington, USA $\left(45.68^{\circ} \mathrm{N}\right.$, $\left.122.72^{\circ} \mathrm{W}\right)$, and sampling location $(\mathbf{O})$. Small box in inset shows location of the study area in Washington State (WA)

the plankton at the dock station to be statistically representative of the lake as a whole (data not shown).

Field sampling. Lake sampling was conducted weekly from April to October 2008, and monthly from November 2008 to January 2009. We used a YSI 95 probe to measure dissolved oxygen and temperature, and a Secchi disk to estimate water clarity. We collected samples of surface lake water, in triplicate, using an acid-washed bucket. From each bucket, 3 to $20 \mathrm{ml}$ of lake water, depending on the period of the bloom cycle, were filtered onto GFF filters, frozen, and then extracted in $90 \%$ acetone. The concentration of chlorophyll a (chl a) was measured using a Turner Model 10 fluorometer by the acidification method (Strickland \& Parsons 1972). An additional $50 \mathrm{ml}$ of lake water from each bucket sample was filtered through a $0.45 \mu \mathrm{m}$ filter, frozen, and then shipped to the University of Washington's School of Oceanography for analysis of nutrient $\left(\mathrm{NO}_{3}, \mathrm{NO}_{2}, \mathrm{NH}_{4}, \mathrm{PO}_{4}, \mathrm{SiO}_{2}\right)$ concentrations using a Technicon AAII system according to the WOCE Hydrographic Program protocols. Finally, $200 \mathrm{ml}$ of lake water from each bucket sample was preserved in $5 \%$ acid Lugol's solution for microscopical analysis to identify and enumerate the protist plankton $<200 \mu \mathrm{m}$ in size (Gifford 1993).

Enumeration and identification of protist plankton. Aliquots of 2 to $25 \mathrm{ml}$ from the Lugol's preserved samples were settled overnight into counting chambers and then examined, at 400× magnification with an Olympus CK40 inverted microscope, to enumerate, size and identify all protists to the genus level, and to species level where possible. For each sample, we counted at least 100 individual cells from randomly selected fields ( $>10$ fields) along transects according to the methods described in Kirchman (1993). Cell biovolume was calculated according to Hillebrand et al. (1999). Carbon biomass was estimated from biovolume using formulas described in Menden-Deuer \& Lessard (2000). Taxa were identified using Wehr \& Sheath (2002) and Patterson (1992).

Microzooplankton grazing experiments. We conducted bi-weekly dilution experiments (following Landry \& Hassett 1982, Landry et al. 1995, Gobler et al. 2007) from April to October 2008 to estimate grazing rates of the microzooplankton and growth rates of the phytoplankton over the course of an entire cyanobacterial bloom cycle. A winter experiment was conducted in January 2009 in order to observe differences in grazing and growth rates due to the seasonal shift in the composition of the plankton community (Table 1).

For each dilution experiment, we collected surface lake water using a clean, acid-washed carboy, then prefiltered the lake water through 73 and $30 \mu \mathrm{m}$ mesh filters before using gravity filtration and a peristaltic pump to filter the water through $0.22 \mu \mathrm{m}$ cellulose filters. We then

Table 1. Dates of dilution experiments, with growth rates and grazing rates calculated from linear regression, and corresponding statistical values. Slopes significantly different from zero: ${ }^{*} p<0.05,{ }^{* *} p<0.01$, ${ }^{* * *} \mathrm{p}<0.001$

\begin{tabular}{|lcrccl|}
\hline $\begin{array}{l}\text { Date of } \\
\text { experiment } \\
(\mathrm{mm} / \mathrm{dd} / \mathrm{yy})\end{array}$ & $\begin{array}{c}\text { Growth rate } \\
\left(\mathrm{d}^{-1}\right)\end{array}$ & $\begin{array}{c}\text { Grazing rate } \\
\left(\mathrm{d}^{-1}\right)\end{array}$ & $\mathrm{r}^{2}$ & $F$ statistic & $\mathrm{p}$ \\
\hline $4 / 1 / 08$ & & & & & \\
$4 / 15 / 08$ & 0.7 & 0.1 & 0.18 & 2.76 & 0.121 \\
$4 / 30 / 08$ & 0.4 & -0.3 & 0.37 & 7.53 & $0.017^{*}$ \\
$5 / 13 / 08$ & 0.9 & 0.2 & 0.11 & 1.56 & 0.234 \\
$6 / 3 / 08$ & 1.2 & 0.3 & 0.34 & 8.17 & $0.013^{*}$ \\
$6 / 16 / 08$ & 0.0 & -0.1 & 0.68 & 26.95 & $0.000^{* * *}$ \\
$6 / 30 / 08$ & -1.3 & -1.5 & 0.30 & 5.52 & $0.035^{*}$ \\
$7 / 14 / 08$ & -0.7 & -1.3 & 0.68 & 27.81 & $0.000^{* * *}$ \\
$7 / 28 / 08$ & -0.2 & -1.1 & 0.89 & 104.8 & $0.000^{* * *}$ \\
$8 / 11 / 08$ & 0.8 & 0.4 & 0.27 & 4.84 & $0.047^{*}$ \\
$8 / 25 / 08$ & 0.9 & 0.0 & 0.00 & 0.03 & 0.859 \\
$9 / 10 / 08$ & 0.4 & 0.3 & 0.33 & 6.52 & $0.024^{*}$ \\
$9 / 22 / 08$ & 1.0 & 0.5 & 0.31 & 5.73 & $0.032^{*}$ \\
$10 / 6 / 08$ & 1.1 & 0.8 & 0.59 & 18.87 & $0.001^{* *}$ \\
$10 / 20 / 08$ & 0.9 & 0.6 & 0.40 & 8.82 & $0.011^{*}$ \\
$1 / 12 / 09$ & 0.9 & 0.7 & 0.69 & 28.89 & $0.000^{* * *}$ \\
& -0.8 & -0.9 & 0.64 & 23.13 & $0.000^{* * *}$ \\
\hline
\end{tabular}


collected additional unfiltered water from the lake in a separate clean, acid-washed carboy. The filtered and unfiltered lake water samples were kept at lake temperature throughout the experimental set-up.

Using 11 polycarbonate bottles, we prepared triplicate dilutions of ambient lake water in filtered lake water in the following ratios: 1:0, 0.75:0.25, 0.5:0.5, 0.25:0.75 and 0.1:0.9. We then added $227 \mu \mathrm{l}$ of $85 \mathrm{~g}$ $\mathrm{mol}^{-1} \mathrm{NaNO}_{3}$ and $420 \mu \mathrm{l}$ of $225 \mathrm{~g} \mathrm{~mol}^{-1} \mathrm{NaH}_{2} \mathrm{PO}_{4} \cdot \mathrm{H}_{2} \mathrm{O}$ to each incubation bottle to ensure nutrient-replete conditions (final concs.: $1.7 \mathrm{~g} \mathrm{l}^{-1} \mathrm{NaNO}_{3}$ and $0.2 \mathrm{~g} \mathrm{l}^{-1}$ $\mathrm{NaH}_{2} \mathrm{PO}_{4} \cdot \mathrm{H}_{2} \mathrm{O}$ ). These concentrations were similar to the maximum levels observed in a comparable lake located in New York (C. J. Gobler pers. comm.). The bottles were incubated for $24 \mathrm{~h}$ on a Plexiglas plankton wheel revolving at $0.5 \mathrm{rpm}$. The plankton wheel was housed in a temperature-controlled room under ambient light and temperature conditions. Each treatment was sampled for chl a concentration at the beginning and end of the $24 \mathrm{~h}$ incubation.

In every other experiment (approximately once per month), we also preserved $200 \mathrm{ml}$ subsamples from every incubation bottle in 5\% Lugol's iodine solution for enumeration and identification of protists $<200 \mu \mathrm{m}$, as described in 'Field sampling' above.

Analysis of growth and grazing rates. For each dilution experiment, we estimated net phytoplankton growth rates based on the change in chl a concentration over the course of the $24 \mathrm{~h}$ incubation, assuming exponential growth. Linear regression analyses of the relationship between net growth rate of phytoplankton and the fraction of unfiltered lake water were then conducted, using Prism version 5.0c for Macintosh statistical software; the intrinsic phytoplankton growth rate was estimated as the $y$-intercept of the regression, and the microzooplankton grazing rate was estimated as the slope of the regression line (Landry \& Hassett 1982, Landry et al. 1995, Gobler et al. 2007). We tested whether the regression slopes were significantly different from zero $(\mathrm{p}<0.05)$ in each experiment using an F-test (Zar 1996). For those experiments in which protists were enumerated and identified, we also estimated taxon-specific growth rates and microzooplankton grazing rates on specific prey categories and phytoplankton size classes.

\section{RESULTS}

\section{Water quality and plankton composition}

Over the sampling period of $10 \mathrm{mo}$, surface lake temperatures ranged from 6 to $25^{\circ} \mathrm{C}$, with the maximum in August 2008 and minimum in January 2009 (Fig. 2A). Dissolved oxygen concentrations averaged $\sim 5.0 \mathrm{mg} \mathrm{l}^{-1}$ over the study period, with a minimum of $3.9 \mathrm{mg} \mathrm{l}^{-1}$ in early October and maximum of $23.7 \mathrm{mg} \mathrm{l}^{-1}$ in January 2009 (Fig. 2A).

Phytoplankton biomass, as measured by chl a concentration, was relatively low in the spring, ranging between 4 and $27 \mu \mathrm{g}$ chl $a \mathrm{l}^{-1}$, then rapidly increased to an initial peak of $256 \mu \mathrm{g} \mathrm{chl} \mathrm{a} \mathrm{^{-1 }}$ in late July, followed by a much larger peak

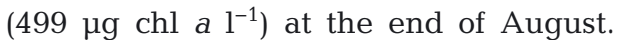
$\mathrm{Chl}$ a concentrations decreased rapidly in October and remained relatively low

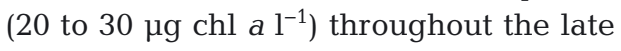
autumn and early winter (Fig. 2B).

Surface concentrations of dissolved inorganic phosphate $\left(\mathrm{PO}_{4}\right)$ peaked just prior to maximum chl a levels, reaching $0.1 \mathrm{mg} \mathrm{l}^{-1}$, while ammonium $\left(\mathrm{NH}_{4}\right)$ concentrations reached a maximum $(0.3 \mathrm{mg}$ $\mathrm{l}^{-1}$ ) coincident with the algal biomass peak (Fig. 2B). Nitrate $\left(\mathrm{NO}_{3}\right)$ and nitrite $\left(\mathrm{NO}_{2}\right)$ concentrations remained relatively low during this period (0.7 to $4.5 \mu \mathrm{g} \mathrm{l}^{-1}$; Fig. 2B). The N:P ratio also remained relatively low (0.6:1 to 19:1) prior to, during, and just after the peak in $\operatorname{chl} a$, then became relatively high $(45: 1)$ in the winter. Autumn and winter (November through January) had the highest nitrate
Fig. 2. Seasonal trends of (A) mean surface concentration of chlorophyll a (chl a), surface temperature and concentration of dissolved oxygen (DO), and (B) mean surface concentrations of chl a and dissolved inorganic phosphate $\left(\mathrm{PO}_{4}\right)$, nitrate $\left(\mathrm{NO}_{3}\right)$, nitrite $\left(\mathrm{NO}_{2}\right)$, ammonium $\left(\mathrm{NH}_{4}\right)$ and silicate $\left(\mathrm{SiO}_{4}\right)$ collected in Vancouver Lake from April 2008 to January 2009 


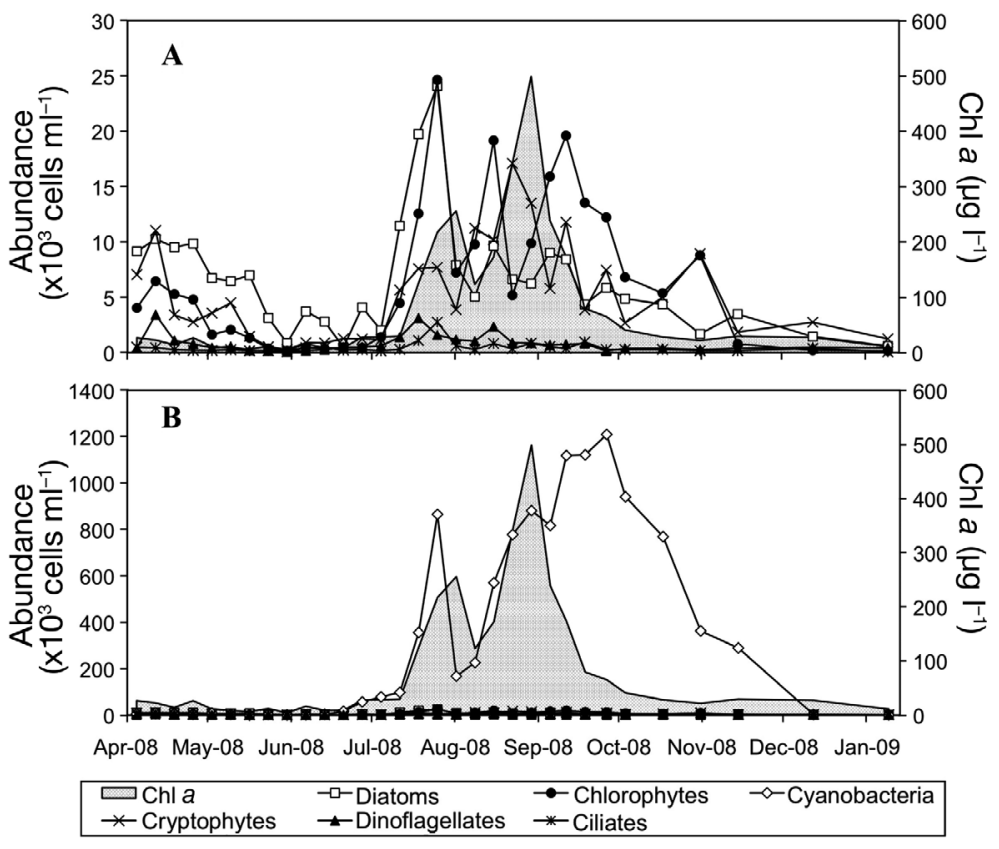

Fig. 3. Mean abundance of major taxonomic groups of protist plankton and mean surface concentration of chlorophyll a (chl a) (A) without cyanobacteria, and (B) including cyanobacteria collected in Vancouver Lake from April 2008 to January 2009

and silicate $\left(\mathrm{SiO}_{4}\right)$ concentrations, with nitrate increasing over 100-fold from low summer levels to $569 \mathrm{\mu g} \mathrm{l}^{-1}$ in January 2009, and silicate reaching a peak of 6.2 $\times 10^{3} \mu \mathrm{g} \mathrm{l}^{-1}$ in October (Fig. 2B).

The overall abundance of protist plankton $(<200 \mu \mathrm{m}$ in size) in Vancouver Lake was relatively low from May to early July, but increased dramatically from late July through August 2008 (Fig. 3A). Diatoms (primarily Aulacosira spp.) and chlorophytes (mainly Scenedesmus spp.) peaked in late July, and cryptophytes (dominated by Cryptomonas sp.) peaked in midAugust. Dinoflagellates (Ceratium hirundinella and assorted athecate taxa) and ciliates (Strombidium spp. and assorted oligotrichs) were also most abundant in late July and early August, but their abundances were always substantially lower than observed for the other protist

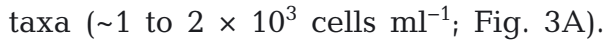
Cyanobacteria reached an initial peak in abundance in late July $\left(8.6 \times 10^{5}\right.$ cells $\mathrm{ml}^{-1}$ ), concurrent with the initial peak in chl $a$, then reached their highest abundance in late September $\left(1.2 \times 10^{6}\right.$ cells $\mathrm{ml}^{-1}$ ) after the chl a bloom, and remained in high abundance through October (Fig. 3B). In terms of biomass, the microplankton community shifted from dominance by diatoms in the spring to cyanobacteria in the summer and autumn (Fig. 4). Ciliate and cryptophyte biomass was relatively high in the winter (December and January) at nearly 40 and $50 \%$ of the total biomass, respectively, but lower during the remainder of the study period (Fig. 4).

The cyanobacteria in Vancouver Lake consisted of a mixed assemblage of species from April through June; however, over the course of several weeks in July and early August they became steadily less diverse and were eventually dominated by filamentous Aphanizomenon flos-aquae from September to December 2008 (Fig. 5A). Anabaena flos-aquae was also present in substantial numbers from April through October, and comprised over $25 \%$ of the abundance of cyanobacteria in late August, just prior to the second peak of chl a (Fig. 5A). In terms of carbon biomass, the dominant cyanobacterial taxon was Aphanizomenon flos-aquae, except during May when Synechococcus spp. and Microcystis spp. were abundant (Fig. 5B).

\section{Rates of phytoplankton growth and microzooplankton grazing}

Of the 16 dilution experiments conducted between April 2008 and January 2009, 13 resulted in regression slopes that were significantly different from zero (Table 1, Fig. 6). Hereafter, we will discuss only the results from these 13 experiments. Intrinsic phytoplankton growth rates were low $\left(0.4 \mathrm{~d}^{-1}\right)$ in April, but increased to $1.2 \mathrm{~d}^{-1}$ in May (Fig. 7). However, zero or negative intrinsic algal growth rates were observed in June through mid-July, indicating that phytoplankton were actually decreasing in biomass over the course of the $24 \mathrm{~h}$ incuba-

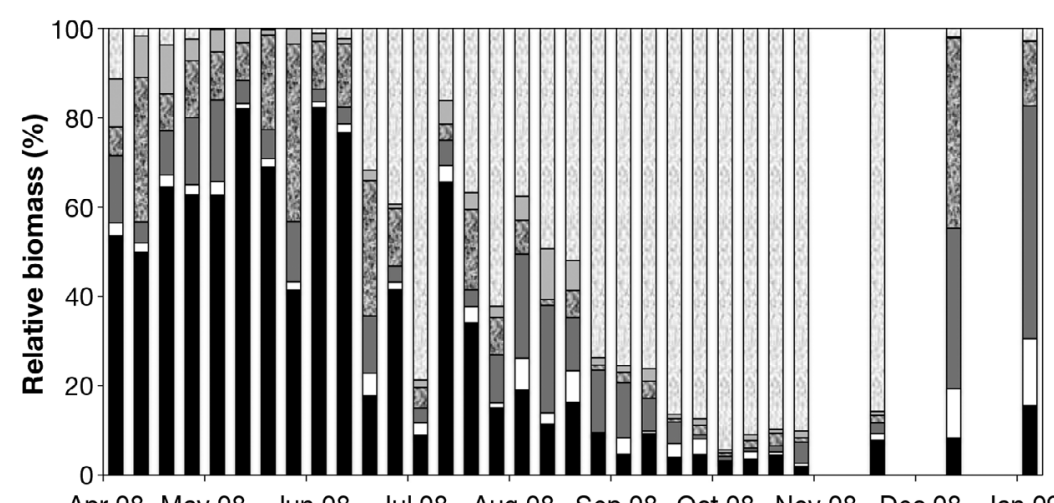

Apr 08 May 08 Jun 08 Jul 08 Aug 08 Sep 08 Oct 08 Nov 08 Dec 08 Jan 09

\begin{tabular}{|lll|}
\hline Diatoms & $\square$ Dinoflagellates & $\square$ Cryptophytes \\
囷 Ciliates & $\square$ Chlorophytes & $\square$ Cyanobacteria \\
\hline
\end{tabular}

Fig. 4. Relative biomass of major taxonomic groups of microplankton (2 to $200 \mu \mathrm{m}$ ) collected in Vancouver Lake from April 2008 to January 2009 


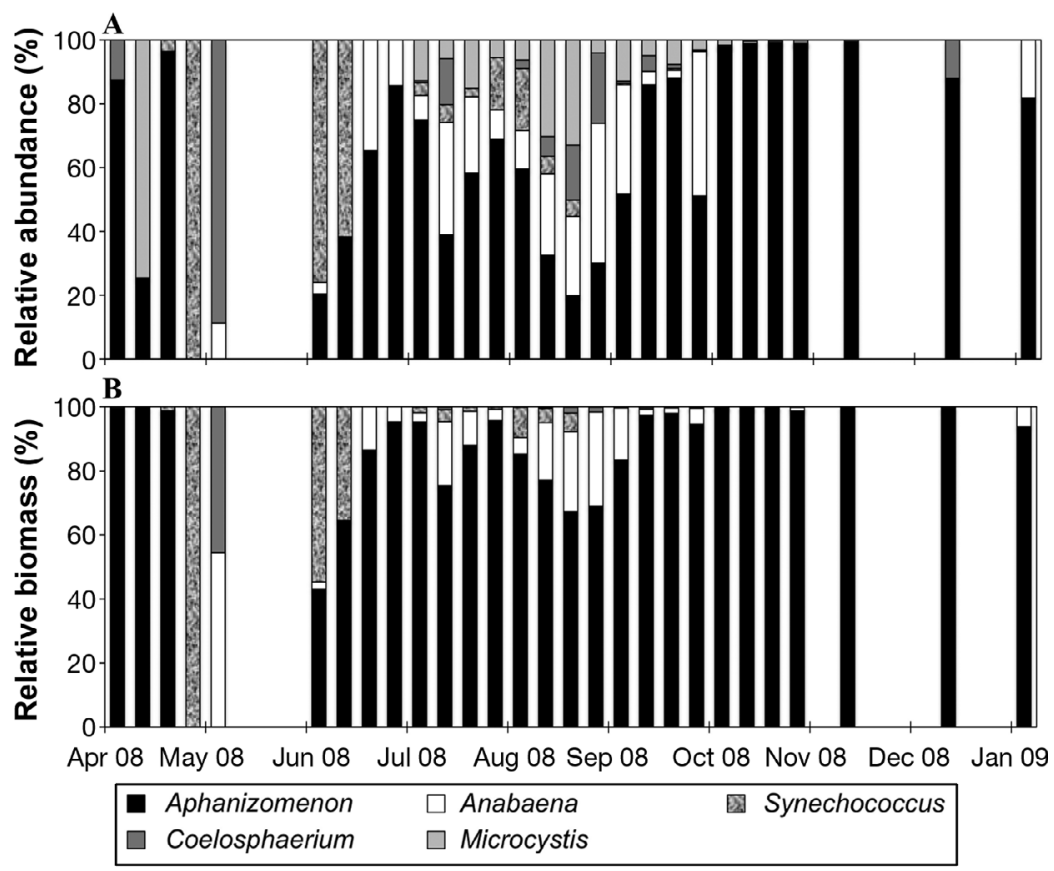

Fig. 5. (A) Relative abundance and (B) relative biomass of cyanobacterial genera collected in Vancouver Lake from April 2008 to January 2009
Microzooplankton grazing rates estimated from the dilution experiments were low ( -0.3 to $0.3 \mathrm{~d}^{-1}$ ) in spring, then became substantially negative $(-1.1$ to $-1.5 \mathrm{~d}^{-1}$ ) in the $6 \mathrm{wk}$ preceding the initial chl a bloom in the lake (Fig. 7). Negative microzooplankton grazing rates indicate that net phytoplankton growth rates in each dilution treatment increased across the spectrum from highest dilution (lowest relative abundance of grazers) to lowest dilution (highest abundance of grazers). During experiments in autumn, microzooplankton grazing rates quickly and dramatically increased, more than doubling from late August to mid-September, then reached a maximum of 0.8 $\mathrm{d}^{-1}$ just after the maximum peak of chl a and remained comparatively high (from 0.3 to $0.8 \mathrm{~d}^{-1}$ ) through the decline of the chl a bloom in early October. In January 2009, the microzooplankton grazing rate was again negative (Fig. 7). tions. Intrinsic phytoplankton growth rates rose in September, just after the peak in chl a concentration, to a maximum of $1.1 \mathrm{~d}^{-1}$, then declined through autumn as the bloom declined. Negative intrinsic algal growth rates were observed again in January 2009 (Fig. 7).

\section{Taxon-specific grazing rates}

In a subset of experiments, we also calculated intrinsic phytoplankton growth rates and microzooplankton grazing rates for particular prey groups based on
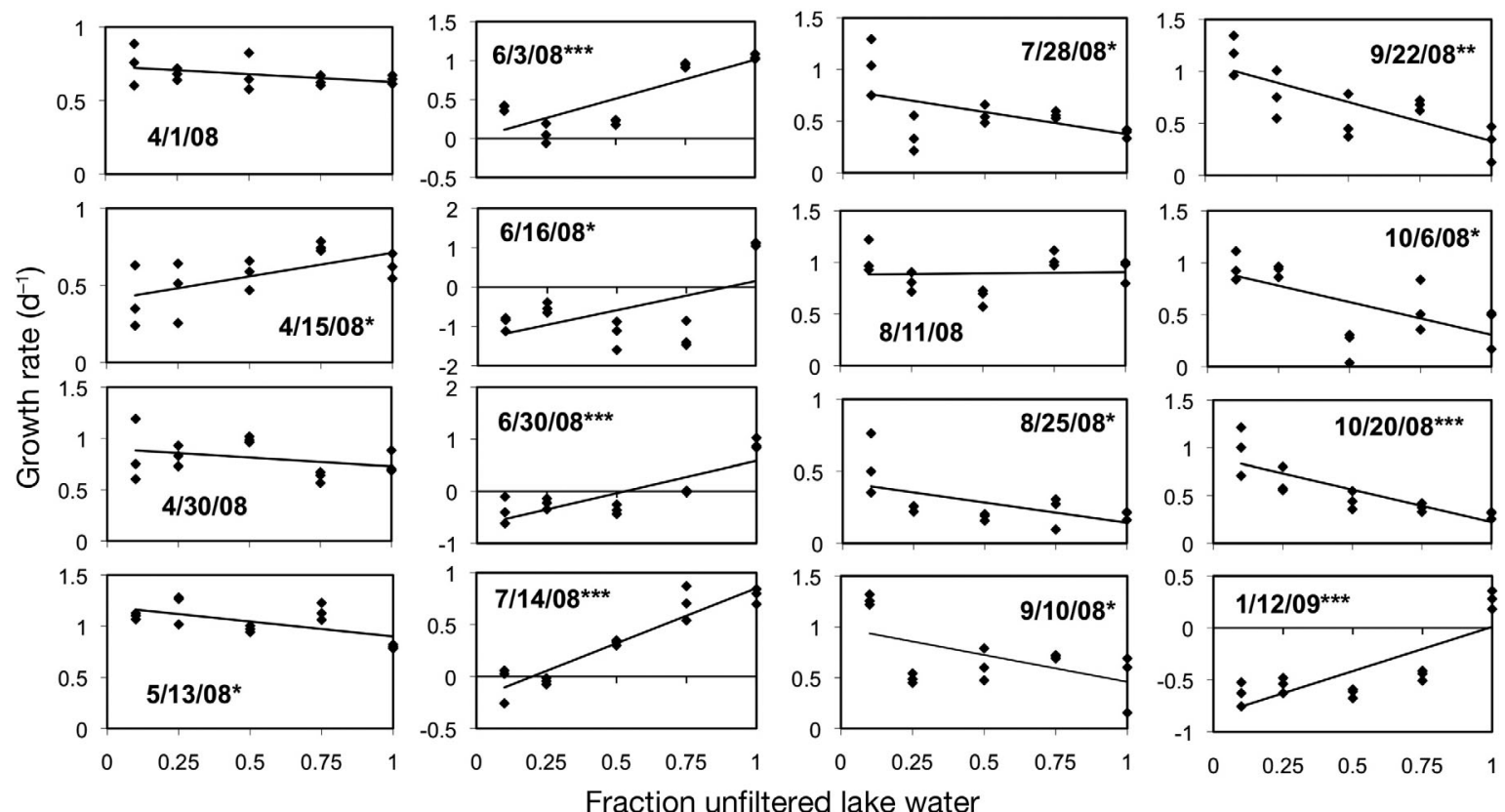

Fraction unfiltered lake water

Fig. 6. Dilution plots showing change in net phytoplankton growth rates with increasing dilution in Vancouver Lake as measured by changes in concentration of chlorophyll a (chl a). Dates are given as mm/dd/yy. Slopes significantly different from zero: ${ }^{*} \mathrm{p}<0.05,{ }^{* *} \mathrm{p}<0.01,{ }^{* * *} \mathrm{p}<0.001$ 


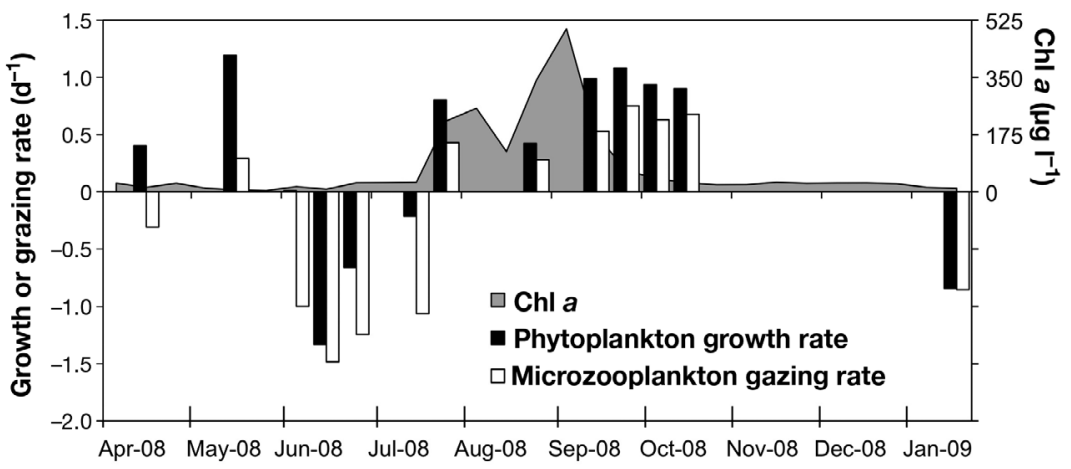

Fig. 7. Intrinsic phytoplankton growth rates $\left(\mathrm{d}^{-1}\right)$ and microzooplankton grazing rates $\left(\mathrm{d}^{-1}\right)$ determined from dilution experiments conducted in Vancouver Lake from April 2008 to January 2009. Shaded area represents mean concentrations of chlorophyll a $(\mathrm{chl} \mathrm{a})$ measured on the date of each experiment

5 experiments examined. Conversely, cryptophytes experienced negative microzooplankton grazing mortality rates in the spring and summer experiments before the chl a bloom, meaning that these organisms increased in abundance over the incubation period even though microzooplankton grazers were present (Fig. 8). It should be noted that while the magnitude of negative grazing on cryptophytes in June was substantially higher than it was for the other taxa, the relative abundance of cryptophytes was extremely low (867 cells $\mathrm{ml}^{-1}$, or $11 \%$ of the phytoplankton population) at that time. Cyanobacteria also experienced negative microzoo-

changes in their abundance over the incubation period. Algal and cyanobacterial growth rates and microzooplankton grazing rates obtained via cell enumeration in selected experiments in May, June, July, September and October, mirrored rates calculated on the basis of chl a concentrations (Fig. 8). The only exception was in July, when the intrinsic phytoplankton growth rate calculated from changes in cell number was twice the magnitude of the chl a-based rate, and the microzooplankton grazing rate was half the magnitude of the chl a-based rate (data not shown).

Microzooplankton grazing rates on major algal taxonomic groups, based on cell enumeration, showed that cyanobacteria were the taxon most heavily grazed upon in May $\left(0.97 \mathrm{~d}^{-1}\right)$, shifting to diatoms in early summer $\left(0.4 \mathrm{~d}^{-1}\right)$, then chlorophytes in mid-summer and into autumn (0.7 to $0.9 \mathrm{~d}^{-1}$; Fig. 8). Cyanobacteria, in particular Aphanizomenon flos-aquae, were again the prey group most heavily grazed in October $\left(0.31 \mathrm{~d}^{-1}\right.$; Fig. 8). Notably, microzooplankton grazing rates on Anabaena flos-aquae were not significant in any of the

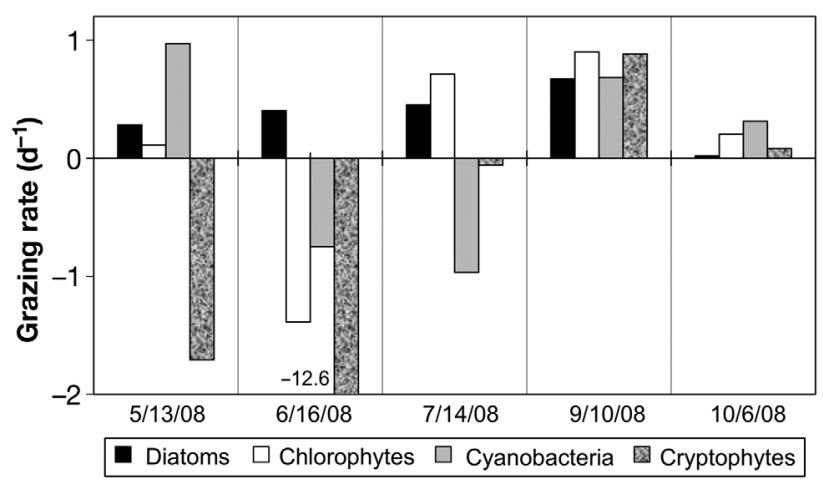

Fig. 8. Microzooplankton grazing rates $\left(\mathrm{d}^{-1}\right)$ on major prey taxonomic groups, based on cell enumeration of dilution experiments conducted in Vancouver Lake. Dates are given as $\mathrm{mm} / \mathrm{dd} / \mathrm{yy}$ plankton grazing rates in the June and July experiments, with the lowest grazing rate on cyanobacteria in July $\left(-1.0 \mathrm{~d}^{-1}\right)$ occurring immediately before the chl $a$ bloom. Only diatoms experienced positive microzooplankton grazing mortality in every experiment (Fig. 8).

Microzooplankton grazing rates on different size classes of prey within each major taxonomic group, compared with their relative abundance, are shown in Fig. 9. In May, small $(<10 \mu \mathrm{m})$ diatoms were the most abundant prey but they experienced negative grazing mortality $\left(-3.0 \mathrm{~d}^{-1}\right)$, while cyanobacteria $(<10 \mu \mathrm{m})$ comprised $<25 \%$ of the prey community but were grazed upon the most $\left(1.0 \mathrm{~d}^{-1}\right)$ (Fig. 9). In June, small cryptophytes comprised a very small proportion of the total prey commu-

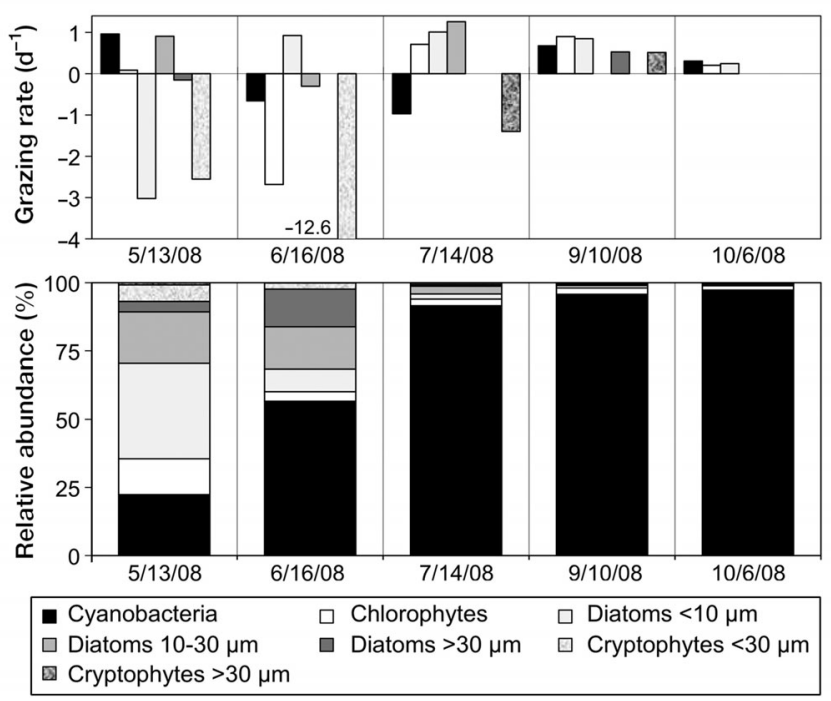

Fig. 9. (A) Microzooplankton grazing rates $\left(\mathrm{d}^{-1}\right)$ according to size classes within major prey taxonomic groups, and (B) relative abundance of major prey taxonomic groups according to size class, based on cell enumeration collected from dilution experiments conducted in Vancouver Lake. Dates are given as $\mathrm{mm} / \mathrm{dd} / \mathrm{yy}$ 
nity and the microzooplankton grazing rate on these cells was substantially negative $\left(-12.6 \mathrm{~d}^{-1}\right.$; Fig. 9). In July, just prior to the bloom, cyanobacteria $(<10 \mu \mathrm{m})$ were the most abundant prey and experienced negative grazing mortality $\left(-0.7 \mathrm{~d}^{-1}\right.$ and $\left.-1.0 \mathrm{~d}^{-1}\right)$; but grazing on cyanobacteria $(<10 \mu \mathrm{m})$ was positive $\left(0.7 \mathrm{~d}^{-1}\right.$ and $\left.0.3 \mathrm{~d}^{-1}\right)$ during experiments in autumn (Fig. 9).

\section{DISCUSSION}

\section{Seasonal pattern of abundance and composition of protist plankton}

The $2008 \mathrm{chl}$ a bloom in Vancouver Lake was intense and appeared rapidly, as demonstrated by an increase in chl $a$ of $>400 \mu \mathrm{g} \mathrm{l}^{-1}$ over the course of only 2 to $3 \mathrm{wk}$ in late July to early August. The chl a bloom was strongly dominated by cyanobacteria, and the abundance of these organisms was so high that Vancouver Lake was closed to public water contact during most of August 2008. Chl a quickly diminished in autumn and returned to low levels in winter, but the abundance of cyanobacteria remained high into October. This may have been due to our inadvertently enumerating post-bloom senescent cyanobacterial cells in which chl a had been degraded, in addition to actively growing cells. Moreover, Aphanizomenon flos-aquae, the dominant cyanobacterial taxon during this period, formed densely packed clumps that were resistant to disaggregation, which complicated enumeration and may have led to an overestimation of the number of cells present.

The abundance of heterotrophic-mixotrophic protists, chiefly ciliates and dinoflagellates, followed a pattern that generally mirrored that of phytoplankton. Ciliate abundance was lowest ( 10 to 50 cells ml $\left.{ }^{-1}\right)$ in June and early July, the weeks just prior to the cyanobacterial bloom of 2008, but reached a maximum of 2800 cells ml ${ }^{-1}$ just $2 \mathrm{~d}$ before the first peak in chl $a$ concentration, and remained elevated throughout the cyanobacterial bloom. Similar patterns of high ciliate abundance during phytoplankton blooms have been observed in other temperate lakes (Biyu 2000, Nakano et al. 2001) and suggest a trophic relationship between these micrograzers and phytoplankton; this was also borne out by the results of our dilution experiments.

\section{Phytoplankton growth and microzooplankton grazing over a bloom cycle}

During spring 2008, phytoplankton growth rates in Vancouver Lake were moderate to high $\left(1.2 \mathrm{~d}^{-1}\right.$ in May), aligned with a period of relatively high abundances of eukaryotic algae (diatoms and chlorophytes); microzooplankton grazing rates were generally low, typical of a spring algal bloom in temperate lakes. However, over 4 consecutive dilution experiments conducted in June and early July 2008 , just prior to the large cyanobacterial bloom, phytoplankton growth rates and microzooplankton grazing rates were both negative.

Although negative microzooplankton grazing rates have been reported in other dilution experiment studies (e.g. Pearce et al. 2008, Rollwagen-Bollens et al. 2011), the negative growth and grazing rates observed in our experiments were quite unexpected and could have been the result of several factors. For instance, if microzooplankton were selectively grazing on a particular algal group that comprised only a small portion of the total phytoplankton abundance, this may have allowed other phytoplankton to proliferate faster than they might otherwise have done without grazers present. The resulting high growth rates of the nongrazed taxa could have exceeded the loss rate of the grazed taxa, leading to apparently higher overall phytoplankton growth in the undiluted treatments with more grazers. It has been demonstrated that microzooplankton may exhibit selective grazing on phytoplankton taxa, regardless of the relative abundance of the desired taxa (Burkill et al. 1987, Verity 1991, Gaul \& Antia 2001). Indeed, during our June 2008 experiments, when overall chl a-based phytoplankton growth rates were negative, the taxonspecific grazing rate was high $\left(1.0 \mathrm{~d}^{-1}\right)$ on small $(<10 \mu \mathrm{m})$ diatoms while grazing rates were strongly negative for the other prey taxa (Fig. 9).

The negative grazing rates could also have been the result of a 'trophic cascade' effect within the treatment bottles. The ambient assemblage of protist grazers in planktonic systems is often highly diverse with respect to taxonomy, size and relative abundance (Reckermann \& Veldhuis 1997), particulary among heterotrophic ciliates (e.g. Zingel \& Noges 2010). If, during our dilution treatments, the protist community consisted of a 3-trophic-level system - with larger, less abundant micrograzers (e.g. ciliates) feeding on smaller, more abundant nanograzers (e.g. heterotrophic flagellates) feeding on even smaller and more abundant pico- or nanophytoplankton - then, as dilution increased, the larger micrograzers could have been selectively removed, allowing the smaller grazers to exert higher grazing pressure on phytoplankton compared to less dilute treatments. Such top down trophic interactions within the protist community have been observed in a range of aquatic environments, as well as in a set of dilution experiments conducted in the Arabian Sea (reviewed in Verity \& Smetacek 1996), and were recently modeled to occur in dilution experiments by First et al. (2009). This process could translate into a 
negative grazing rate, where net phytoplankton growth was higher in the undiluted treatments.

Finally, some strains of Anabaena flos-aquae may produce potent toxins; Anabaena flos-aquae became relatively abundant in Vancouver Lake during June and July 2008. If this organism or any other toxic species had been producing toxins during this time, the negative grazing rates in our experiments could also have been due to increasing toxicity of the water used for dilution (Landry 1993). No measurements of cyanotoxin concentrations were made in Vancouver Lake during this period, so this remains an open question.

As the chl a bloom in Vancouver Lake progressed through August and September 2008, there was a rapid increase in both phytoplankton growth rates $(0.5$ to $1.0 \mathrm{~d}^{-1}$ ) and microzooplankton grazing rates (0.3 to $0.8 \mathrm{~d}^{-1}$ ), ranges that are consistent with observations from other aquatic systems. For example, in an extensive review, Calbet \& Landry (2004) found average phytoplankton growth rates of $0.69 \mathrm{~d}^{-1}$ and microzooplankton grazing rates of $0.40 \mathrm{~d}^{-1}$ for temperate marine systems. Our results also compare favorably with studies conducted in coastal and estuarine systems, where phytoplankton growth rates ranged from 0.1 to $1.23 \mathrm{~d}^{-1}$ and grazing rates ranged from 0.05 to $1.22 \mathrm{~d}^{-1}$ (Murrell \& Hollibaugh 1998, Lignell et al. 2003, Loebl \& Van Beusekom 2008, Rollwagen-Bollens et al. 2011). Similarly, Leising et al. (2005) found phytoplankton growth rates $>0.5 \mathrm{~d}^{-1}$ in Dabob Bay, Washington, USA, during a spring phytoplankton bloom, and Demir et al. (2008) observed phytoplankton growth rates from 0.21 to $1.54 \mathrm{~d}^{-1}$ and microzooplankton grazing rates from 0.11 to $0.82 \mathrm{~d}^{-1}$ during phytoplankton blooms in Delaware inland bays.

In freshwater environments, we are aware of only 2 other studies that conducted dilution experiments to measure the grazing rates of microzooplankton in association with cyanobacterial blooms, and our results are comparable to both. Leonard \& Paerl (2005) measured a phytoplankton growth rate of $0.58 \mathrm{~d}^{-1}$ and a microzooplankton grazing rate of $0.5 \mathrm{~d}^{-1}$ during a bloom of Cylindrospermosis cyanobacteria in Lake George, part of the St. Johns River system in Florida, and Gobler et al. (2007) recorded a phytoplankton growth rate of $1.03 \mathrm{~d}^{-1}$ and a microzooplankton grazing rate of $0.35 \mathrm{~d}^{-1}$ at the height of an Anabaena cyanobacterial bloom in Lake Agawam, New York, USA.

As the chl a bloom in Vancouver Lake declined in the autumn of 2008, phytoplankton growth rates in the incubation bottles remained high (0.90 to $\left.0.94 \mathrm{~d}^{-1}\right)$, as did the microzooplankton grazing rates (0.63 to $0.68 \mathrm{~d}^{-1}$ ). Our high growth and grazing rates following the cyanobacterial bloom contrast somewhat with observations from the other 2 studies of microzoo- plankton grazing on freshwater cyanobacterial blooms. For instance, Gobler et al. (2007) found that phytoplankton growth rates in Lake Agawam fell to $0.71 \mathrm{~d}^{-1}$, and microzooplankton grazing rates decreased to $0.36 \mathrm{~d}^{-1}$ after the peak of a phytoplankton bloom from September to October. Similarly, Leonard $\&$ Paerl (2005) saw a relatively low growth rate $\left(0.2 \mathrm{~d}^{-1}\right)$ and low grazing rate $\left(0.22 \mathrm{~d}^{-1}\right)$ in the autumn after the cyanobacterial bloom.

The high growth rates in our post-bloom experiments may have been the result of persistent warm temperatures and an overall decreased abundance of phytoplankton, which could have reduced competition for resources (light, nutrients) and allowed higher growth rates (Wehr \& Sheath 2002). Higher microzooplankton grazing rates in the autumn may have been the result of a change in the composition of the phytoplankton community away from dominance by cyanobacteria, possibly providing the microzooplankton greater availability of prey that were preferable to cyanobacteria.

\section{Selective microzooplankton grazing on cyanobacteria and algae}

The microscopical analysis of a subset of the dilution experiments yielded interesting information on potential predator-prey interactions and on the impact of grazing by microzooplankton on particular phytoplankton species. Diatoms were the only taxon grazed upon consistently throughout the study period, and small $(<10 \mu \mathrm{m})$ diatoms appeared to be selectively consumed, as there was a significant negative correlation between grazing mortality rate and their relative abundance (Pearson's $\mathrm{r}=-0.25, \mathrm{p}=0.01$ ). Microzooplankton have been observed to selectively consume small $(<25 \mu \mathrm{m})$ phytoplankton in a freshwater reservoir (Tadonléké \& Sime-Ngando 2000). Moreover, diatoms can be high in nutritional value (Volkman et al. 1989), while cyanobacteria have been recognized as a poor food source because their cell walls are resistant to digestion, they may contain toxins, and their filamentous colonies are difficult to graze upon (Allan 1995). Diatoms may have been preferable even when in very low abundance because of their higher nutritional value, and ease of being ingested, compared to cyanobacteria. Similarly, microzooplankton grazed on chlorophytes and cryptophytes after the bloom peak, even though cyanobacteria were the dominant taxa during this period, suggesting that the microzooplankton may again have been selecting prey preferable to cyanobacteria.

However, microzooplankton did graze directly on cyanobacteria in the spring before the bloom and 
during the autumn as the bloom was declining. The relatively high rate of grazing by microzooplankton on cyanobacteria in spring may have been due to the relative availability of non-filamentous taxa during this time (e.g. Aphanocapsa, Coelosphaerium). Tijdens et al. (2008) saw no microzooplankton grazing on filamentous cyanobacteria in a shallow Dutch lake, but microzooplankton did graze on unicellular cyanobacteria ( 0.45 to $1.25 \mathrm{~d}^{-1}$ ), suggesting that they may select for different species of cyanobacteria based on morphology. Indeed, the ciliate Nassula aurea was observed grazing on Anabaena flosaquae in temperate lakes in Cumbria, UK, and increased numbers of $N$. aurea were coincident with declines in Anabaena sp. complexes (Canter et al. 1990).

But in the weeks leading up to the dramatic increase in cyanobacterial abundance in Vancouver Lake, microzooplankton grazing rates on cyanobacteria in our experiments were negative. As already discussed above for our chl a-based grazing rates, this could have been the result of preferential grazing by microzooplankton on other co-occurring prey, namely diatoms, which could have released the cyanobacteria from grazing pressure in the incubations. A similar pattern of preferential grazing on diatoms by microzooplankton during a cyanobacterial bloom was also observed in the St. Johns River system in Florida, USA (Leonard \& Paerl 2005).

Interestingly, the peak abundance of cyanobacteria in Vancouver Lake did not appear until late July 2008, despite negative grazing rates measured in the late June to early July dilution experiments. In a companion study, Rollwagen-Bollens et al. (unpubl. data) measured the grazing rates and prey selectivity of the cyclopoid copepod Diacyclops thomasi in concurrent experiments over the period summer to autumn of 2008. In early July, D. thomasi preferentially consumed ciliates, the most common protistan microzooplankton taxa present in Vancouver Lake. Selective predation by copepods could have significantly reduced the grazing pressure of microzooplankton (ciliates) on their preferred diet of diatoms during this period, allowing diatoms to successfully compete with cooccurring cyanobacteria. After the July experiments ciliate abundance increased substantially, suggesting that selective microzooplankton grazing on diatoms could have resumed, allowing cyanobacteria to quickly increase in abundance and form the bloom. But by September and October, as the bloom was declining, microzooplankton grazing rates on cyanobacteria, in particular Aphanizomenon flos-aquae, were high $\left(0.3\right.$ to $\left.0.7 \mathrm{~d}^{-1}\right)$

In summary, rates of microzooplankton grazing on the overall phytoplankton community in Vancouver
Lake were relatively low during spring 2008, and became substantially negative in dilution experiments conducted in the weeks prior to a large cyanobacterial bloom in August to September. However, taxonomic analysis of dilution experiment samples showed microzooplankton selectively consumed small diatoms and avoided co-occurring phytoplankton prior to the bloom, which may have allowed cyanobacteria to proliferate. Microzooplankton grazing rates were higher during and after the cyanobacterial bloom from August to October 2008, and are likely to have contributed to the bloom's decline. Based on these results we conclude that microzooplankton grazing may have both direct and indirect influences on the timing and decline of freshwater cyanobacterial blooms, and may represent an important factor to consider when devising management strategies to mitigate these blooms in shallow, turbid lakes.

Acknowledgements. We thank the Vancouver Lake Watershed Partnership, the Clark County Department of Public Works, the State of Washington Water Research Center/US Geological Survey, and the Washington Department of Ecology for financial support of this project in the form of grants to G.R.B and S.M.B. We also recognize the National Science Foundation 'GK-12' Program for Fellowship support to J.B. (Award No. 07-42561).

\section{LITERATURE CITED}

Allan JD (1995) Stream ecology: structure and function of running waters. Kluwer Academic Publishers, Dordrecht

Anderson DM, Gilbert PM, Burkholder JM (2002) Harmful algal blooms and eutrophication: nutrient sources, composition and consequences. Estuaries 25:704-726

Beasley VR, Cook WO, Dahlem AM, Hooser SB, Lovell RA, Valentine WM (1989) Algae intoxication in livestock and waterfowl. Vet Clin North Am Food Anim Pract 5: 345-361

Biyu S (2000) Planktonic protozooplankton (ciliates, heliozoans and testaceans) in two shallow mesotrophic lakes in China-a comparative study between a macrophytedominated lake (Biandantang) and an algal lake (Houhu). Hydrobiologia 434:151-163

> Burkill PH, Mantoura RFC, Llewellyn CA, Owens NJP (1987) Microzooplankton grazing and selectivity of phytoplankton in coastal waters. Mar Biol 93:581-590

Calbet A (2008) The trophic roles of microzooplankton in marine systems. ICES J Mar Sci 65:325-331

Calbet A, Landry MR (2004) Phytoplankton growth, microzooplankton grazing, and carbon cycling in marine systems. Limnol Oceanogr 49:51-57

Canter HM, Heaney SI, Lund JWG (1990) The ecological significance of grazing on planktonic populations of cyanobacteria by the ciliate Nassula. New Phytol 114: $247-263$

Carmichael WW (1997) The cyanotoxins. In: Callow JA (ed) Advances in botanical research. Academic Press, London, p 187-209

Caromile SJ, Meyer WR, Jackson CS (2000) 1998 warmwater fish survey of Vancouver Lake, Clark County. Washington 
Department of Fish and Wildlife, Olympia, WA

Carpenter SR, Ludwig D, Brock WA (1999) Management of eutrophication in lakes subject to potentially irreversible change. Ecol Appl 9:751-771

Celik K, Ongun T (2006) Seasonal dynamics of phytoplankton assemblages across nutrient gradients in shallow hypertrophic Lake Manyas, Turkey. Lake Reservoir Manag 22:250-260

Chorus I (2001) Cyanotoxins: occurrence, causes, consequences. Springer-Verlag, Berlin

Chorus I, Falconer IR (2000) Health risks caused by freshwater cyanobacteria in recreational water. J Toxicol Environ Health 3:323-347

Codd GA (1998) Cyanobacterial blooms and toxins in fresh-, brackish and marine waters. In: Reguera B, Bianco J, Fernandez ML, Wyatt T (eds) Harmful algae. Xunta de Galicia and Intergovernmental Oceanographic Commission of UNESCO, Santiago de Compostela, p 13-17

Codd GA (2000) Cyanobacterial toxin, the perception of water quality, and the prioritisation in eutrophication control. Ecol Eng 16:51-60

de Figueiredo DR, Reboleira A, Antunes SC, Abrantes N, Azeiteiro U, Goncalves F, Pereira MJ (2006) The effect of environmental parameters and cyanobacterial blooms on phytoplankton dynamics of a Portuguese temperate lake. Hydrobiologia 568:145-157

Demir E, Coyne KJ, Doblin MA, Handy SM, Hutchins DA (2008) Assessment of microzooplankton grazing on Heterosigma akashiwo using a species-specific approach combining quantitative real-time PCR (QPCR) and dilution methods. Microb Ecol 55:583-594

> Dryden RC, Wright SJL (1987) Predation of cyanobacteria by protozoa. Can J Microbiol 33:471-482

> Elser JJ (1999) The pathway to noxious cyanobacteria blooms in lakes: the food web as the final turn. Freshw Biol 42:537-543

Epp GT (1996) Grazing on filamentous cyanobacteria by Daphnia pulicaria. Limnol Oceanogr 41:560-567

- Fialkowska E, Pajdak-Stós A (2002) Dependence of cyanobacteria defense mode on grazer pressure. Aquat Microb Ecol 27:149-157

First MR, Miller HL III, Lavrentyev PJ, Pinckney JL, Burd AB (2009) Effects of microzooplankton growth and trophic interactions on herbivory in coastal and offshore environments. Aquat Microb Ecol 54:255-267

Gaul W, Antia AN (2001) Taxon-specific growth and selective microzooplankton grazing of phytoplankton in the Northeast Atlantic. J Mar Syst 30:241-261

Gifford DJ (1993) Consumption of protozoa by copepods feeding on natural microplankton assemblages. In: Kemp PF, Sherr BF, Sherr EB, Cole JJ (eds) Handbook of methods in aquatic microbial ecology. Lewis, Boca Raton, FL, p 723-729

Glibert PM, Anderson DA, Gentien P, Graneli E, Sellner KG (2005) The global, complex phenomena of harmful algal blooms. Oceanography 18:136-147

> Gobler CJ, Davis TW, Coyne KJ, Boyer GL (2007) Interactive influences of nutrient loading, zooplankton grazing, and microcystin synthetase gene expression on cyanobacterial bloom dynamics in a eutrophic New York lake. Harmful Algae 6:119-133

> Hallegraeff GM (1993) A review of harmful algal blooms and their apparent global increase. Phycologia 32:79-99

> Hambright KD, Zohary T, Easton J, Azoulay B, Fishbein T (2001) Effects of zooplankton grazing and nutrients on the bloom-forming, $\mathrm{N}_{2}$-fixing cyanobacterium Aphanizomenon in Lake Kinneret. J Plankton Res 23:165-174
Havens KE (2008) Cyanobacterial blooms: effects on aquatic ecosystems. In: Hudnell HK (ed) Cyanobacterial harmful algal blooms: state of science and research needs. Springer, New York, NY, p 733-747

Heisler J, Glibert PM, Burkholder JM, Anderson DM and others (2008) Eutrophication and harmful algal blooms: a scientific consensus. Harmful Algae 8:3-13

Henjes J, Assmy P, Klaas C, Verity P, Smetacek V (2007) Response of microzooplankton (protists and small copepods) to an iron-induced phytoplankton bloom in the Southern Ocean (EisenEx). Deep-Sea Res I 54: 363-384

> Hillebrand H, Dürselen C, Kirschtel D, Pollingher U, Zohary T (1999) Biovolume calculation for pelagic and benthic microalgae. J Phycol 35:403-424

> Jakobsen HH, Tang KW (2002) Effects of protozoan grazing on colony formation in Phaeocystis globosa (Prymnesiophyceae) and the potential costs and benefits. Aquat Microb Ecol 27:261-273

Kirchman DL (1993) Statistical analysis of direct counts of microbial abundance. In: Kemp PF, Sherr BF, Sherr EB, Cole JJ (eds) Handbook of methods in aquatic microbial ecology. CRC Press LLC, Washington, DC, p $117-119$

Landry MR (1993) Estimating rates of growth and grazing mortality of phytoplankton by the dilution method. In: Kemp PF, Sherr BF, Sherr EB, Cole JJ (eds) Handbook of methods in aquatic microbial ecology. CRC Press LLC, Washington, DC, p 715-722

> Landry MR, Hassett RP (1982) Estimating the grazing impact of marine micro-zooplankton. Mar Biol 67:283-288

> Landry MR, Kirshtein J, Constantinou J (1995) A refined dilution technique for measuring the community grazing impact of microzooplankton, with experimental tests in the central equatorial Pacific. Mar Ecol Prog Ser 120: 53-63

Leising AW, Horner R, Pierson JJ, Postel J, Halsband-Lenk C (2005) The balance between microzooplankton grazing and phytoplankton growth in a highly productive estuarine fjord. Prog Oceanogr 67:366-383

> Leonard JA, Paerl HW (2005) Zooplankton community structure, micro-zooplankton grazing impact, and seston energy content in the St. Johns river system, Florida as influenced by the toxic cyanobacterium Cylindrospermopsis raciborskii. Hydrobiologia 537:89-97

Lignell R, Seppald J, Kuuppo P, Tamminen T, Andersen T, Gismervik I (2003) Beyond bulk properties: responses of coastal summer plankton communities to nutrient enrichment in the northern Baltic Sea. Limnol Oceanogr 48: 189-209

Loebl M, Van Beusekom JEE (2008) Seasonality of microzooplankton grazing in the northern Wadden Sea. J Sea Res 59:203-216

Lürling M (2003) Effects of microcystin-free and microcystincontaining strains of the cyanobacterium Microcystis aeruginosa on growth of the grazer Daphnia magna. Environ Toxicol 18:202-210

Menden-Deuer S, Lessard EJ (2000) Carbon to volume relationships for dinoflagellates, diatoms, and other protist plankton. Limnol Oceanogr 45:569-579

> Mitra A, Flynn KJ (2006) Promotion of harmful algal blooms by zooplankton predatory activity. Biol Lett 2:194-197

> Murrell MC, Hollibaugh JT (1998) Microzooplankton grazing in northern San Francisco Bay measured by the dilution method. Aquat Microb Ecol 15:53-63

- Nakano S, Manage PM, Nishibe Y, Kawabata Z (2001) Trophic linkage among heterotrophic nanoflagellates, 
ciliates and metazoan zooplankton in a hypereutrophic pond. Aquat Microb Ecol 25:259-270

Oliver RL, Ganf GG (2000) Freshwater blooms. In: Whitton BA, Potts $M$ (eds) The ecology of cyanobacteria, their diversity in time and space. Kluwer Academic, Dordrecht, p 149-194

Panosso R, Carlsson P, Kozlowski-Suzuki B, Azevado SMFO, Graneli E (2003) Effect of grazing by a neotropical copepod, Notodiaptomus, on a natural cyanobacterial assemblage and on toxic and non-toxic cyanobacterial strains. J Plankton Res 25:1169-1175

Paterson MJ, Findlay DL, Salki AG, Hendzel LL, Hesslein RH (2002) The effects of Daphnia on nutrient stoichiometry and filamentous cyanobacteria: a mesocosm experiment in a eutrophic lake. Freshw Biol 47:1217-1233

Patterson DJ (1992) Free-living freshwater protozoa: a color guide. ASM Press, Washington, DC

Pearce I, Davidson AT, Wright S, van den Enden R (2008) Seasonal changes in phytoplankton growth and microzooplankton grazing at an Antarctic coastal site. Aquat Microb Ecol 50:157-167

Reckermann M, Veldhuis MJW (1997) Trophic interactions between picophytoplankton and micro- and nanozooplankton in the western Arabian Sea during the NE monsoon 1993. Aquat Microb Ecol 12:263-273

Rollwagen-Bollens G, Gifford S, Bollens S (2011) The role of protistan microzooplankton in the upper San Francisco Estuary planktonic food web: source or sink? Estuar Coast (in press) doi:10.1007/s12237-011-9374-x

Smayda TJ (1990) Novel and nuisance phytoplankton blooms in the sea: evidence for a global epidemic. In: Graneli E, Sundstrom B, Edler L, Anderson DM (eds) Toxic marine phytoplankton. Elsevier, New York, NY, p 29-40

Smith VH (1983) Low nitrogen-to-phosphorus ratios favor dominance by blue-green algae in lake phytoplankton. Science 221:669-671

Stewart I, Webb PM, Schluter PJ, Fleming LE and others (2006) Epidemiology of recreational exposure to freshwater cyanobacteria - an international prospective cohort study. BMC Public Health 6:93 doi:10.1186/14712458-6-93

Strickland JDH, Parsons TR (1972) A practical manual for

Editorial responsibility: Klaus Jürgens,

Rostock, Germany seawater analysis, 2nd edn. Fisheries Research Board of Canada, Ottawa

Tadonléké RD, Sime-Ngando S (2000) Rates of growth and microbial grazing mortality of phytoplankton in a recent artificial lake. Aquat Microb Ecol 22:301-313

> Tijdens MT, Van De Waal DB, Slovackova H, Hoogveld HL, Gons HJ (2008) Estimates of bacterial and phytoplankton mortality caused by viral lysis and microzooplankton grazing in a shallow eutrophic lake. Freshw Biol 53:1126-1141

Verity PG (1991) Feeding in planktonic protozoans: evidence for non-random acquisition of prey. J Protozool 38:69-76

Verity PG, Smetacek V (1996) Organism life cycles, predation, and the structure of marine pelagic ecosystems. Mar Ecol Prog Ser 130:277-293

Volkman JK, Jeffrey SW, Nichols PD, Rogers GI, Garland CD (1989) Fatty acids and lipid classes of ten species of microalgae used in mariculture. J Exp Mar Biol Ecol 128:219-240

Wehr JD, Sheath RG (2002) Freshwater algae of North America: ecology and classification. Academic Press, San Diego, CA

Wierenga RE (2005) Volunteer monitoring report-Vancouver Lake annual data summary for 2004. Clark County Public Works Water Resources, Vancouver, WA

Wilson AE, Sarnelle O, Tillmanns AR (2006) Effects of cyanobacteria toxicity and morphology on the population growth of freshwater zooplankton: meta-analyses of laboratory experiments. Limnol Oceanogr 51:1915-1924

Wu SK, Xie P, Liang GD, Wang SB, Liang M (2006) Relationships between microcystins and environmental parameters in 30 subtropical shallow lakes along the Yangtze River, China. Freshw Biol 51:2309-2319

Yamamoto Y (2009) Environmental factors that determine the occurrence and seasonal dynamics of Aphanizomenon flos-aquae. J Limnol 68:122-132

Yang Z, Kong F, Shi X, Cao H (2006) Morphological response of Microcystis aeruginosa to grazing by different sorts of zooplankton. Hydrobiologia 563:225-230

Zar JH (1996) Biostatistical analysis, 3rd edn. Prentice-Hall, Upper Saddle River, NJ

Zingel P, Noges T (2010) Seasonal and annual population dynamics of ciliates in a shallow eutrophic lake. Fundamental Appl Limnol/Arch Hydrobiol 176:133-143

Submitted: July 19, 2010; Accepted: April 19, 2011

Proofs received from author(s): July 24, 2011 